\title{
PSYCHOLOGICAL TIME AND ECONOMIC MIND OF ENTREPRENEURS. EVIDENCE FROM SMALL BUSINESS OF RUSSIAN INDUSTRIAL REGION
}

\author{
Ekaterina Zabelina, Svetlana Kurnosova, \& Ekaterina Vedeneeva \\ Institute of Education and Practical Psychology, Chelyabinsk State University (Russia)
}

\begin{abstract}
Entrepreneurs, as the most active social group sensitive to public mood, perhaps feel the changes in the time of life in a digital society (time pressure illusion) most of all. On the other hand, the very internal temporal organization of a person involved in entrepreneurial activity can determine the characteristics of his or her mind and behavior in the economic sphere. The aim of the study is to reveal the impact of the psychological time of the representatives of small businesses on their economic minds. The study involves 109 representatives of small businesses in various fields (wholesale and retail trade, education, tourism, consulting, production, etc.), registered in the Chelyabinsk region and operating in the Russian Federation (mean age 34.9, 42\% male). The respondents completed electronic forms of Inventory of Time Value as an Economic Resource (Usunier), Zimbardo Time Perspective Inventory, Attitudes towards Time (Nuttin), and Inventory of Polychronic Values (Bluedorn). To diagnose the features of the economic mind of entrepreneurs, the Economic Attitudes Questionnaire (Deyneka \& Zabelina, 2018) was used. Regression analysis showed that certain components of psychological time (positive attitude to the past, present and future, the value of time as an economic resource) determine the formation of constructive economic attitudes of small business owners, namely the value of independent economic achievements, willingness to invest, unwillingness to sacrifice vocation and health for money, financial optimism. Thus, the lack of fixation on past failures, a positive attitude towards the present and the future, the ability to transfer time into money create a psychological foundation for the formation of entrepreneurs' attitudes in economic life. The results can be used in the consulting of the future entrepreneurs.
\end{abstract}

Keywords: Entrepreneurs, psychological time, small businesses, economic mind.

\section{Introduction}

Entrepreneurs are a special category of people, the success of which largely depends on the stable development of the country's economics. This statement is most true for small and medium-sized businesses. However, the reasons for choosing or not doing business in Russia have not been sufficiently studied (Zhuravlev, 2005; Zhuravlev, Kupreichenko, 2007, etc.). In particular, it is not clear what role the psychological time of an individual can play in this choice and success in entrepreneurial activities.

Being the most active social group that are sensitive to public mood, entrepreneurs may feel the changes in the time of life in a digital society (time pressure illusion) most of all. On the other hand, the very internal temporal organization of a person involved in entrepreneurial activity can determine the characteristics of his or her mind and behavior in the economic sphere.

Most of studies in this research area are devoted to the future time perspective of the entrepreneurs (e.g., Przepiorka, 2017). However, there is still no consensus on the future time perspective as a distinctive characteristic of an entrepreneur. For instance, there is a common view that both aspiring and already successful entrepreneurs are highly future-oriented (Przepiorka, 2016; Retsikas, 2017). However, a previous study (the late 1970s) of businessmen (aged from 35 to 64), on the other hand, found that they had a shortened time horizon (LeBlanc, 1969), which was explained by the nature of professional activities associated with uncertain economic risk (LeBlanc,1969).

Since the previous studies (Chen, Nadkarni, 2017; Przepiorka, 2017) showed that entrepreneurs perceive and experience the time of life in a special way, it was suggested that these features have an impact on their economic mind, on how business owners perceive objects and relations of economic reality. At the same time, there is little knowledge about how the psychological time of the entrepreneur's personality and their economic mind and behavior are connected. 
In the modern world economic mind seems to be a reflection of the economic relations and objects that exist not only in the real market but also in the virtual world of goods and services. Although there are various views on the structure of economic mind in science, most scholars note that its essential elements are economic attitudes (Deyneka, 2011; Zabelina E., Deyneka O. and Tsiring D., 2019).

The concept of an attitude has been widely used in social psychology since the first third of the 20th century. In a general sense, attitude is defined as "a relatively enduring organization of beliefs around an object or situation predisposing one to respond in some preferential manner" (Rokeach, 1986, p. 112). Smith observes three components in the structure of attitudes, namely, cognitive, affective, and behavioral one (Smith, 1986). All of these components are closely related, though they even may contradict one another (Conner and Sparks, 2002). The economic attitudes of the individuals and social groups were most actively studied in the last quarter of the 20th century. In particular, there were studied the attitudes toward unemployment (Kalil et al., 2001; Lewis and Furnham, 1986), attitudes toward saving (Furnham, 1985), attitudes in debt and consumer behavior (Lea et al., 1995; Mewse et al., 2010), money attitudes (Furnham, 1996; Von Stumm et al., 2013), and investment attitudes (Antonides and Van Der Sar, 1990). However, most studies do not consider the economic attitudes of the entrepreneurs as a special subject of study.

The lack and inconsistency of data in this knowledge area led to the aim of the study - to reveal the impact of the psychological time of the representatives of small businesses on their economic minds.

\section{Method and sample}

The aim of the study is to reveal the impact of the psychological time of the representatives of small businesses on their economic minds. The study involves 109 representatives of small businesses in various fields (wholesale and retail trade, education, tourism, consulting, production, etc.), registered in the Chelyabinsk region and operating in the Russian Federation (mean age 34.9, 42\% male).

To identify the features of the economic mind of the entrepreneurs, a control group of employees working for hire from various fields of professional activity was formed:

1. IT specialists of commercial organizations (programmers, developers, system administrators) - 111 people aged 19 to 45 years (mean age 26.4 ), 58.5\% male.

2. Employees of state institutions (secondary schools teachers) - 102 people aged 23 to 62 years (mean age 37.5), 25.5\% male.

3. Civil servants (officials, the representatives of the city administration, legislative assembly, judges) - 92 people aged 23 to 65 years (mean age 37.1 ), $43.5 \%$ male.

When determining and forming groups of the respondents, the logic of contrasting characteristics of professional groups was maintained: 1) entrepreneurs vs hard workers; 2) employees of commercial companies vs employees of budgetary (state) institutions. Civil servants are chosen as the most striking contrast to entrepreneurs group, as it represents a certain category according to the Russian legislation. First, civil servants are forbidden to engage in their own business, second, work at the civil service is relatively stable and predictable; third, their activities are strictly regulated, therefore, it gives a modest place to risk and creativity. All these characteristics of professional activity are opposed to entrepreneurship, where risk, uncertainty, and creativity come first. Among the commercial organizations, companies working in the field of information technology were selected, since this direction is actively developing at the present time and brings high revenues to companies.

The respondents completed electronic forms of Inventory of Time Value as an Economic Resource by Usunier (Nestik, 2015), Zimbardo Time Perspective Inventory (Zimbardo, Boyd, 1999; Mitina, Sircova, 2008), Attitudes towards Time (Nuttin, 2004), and Inventory of Polychronic Values by Bluedorn (Nestic, 2015). To diagnose the features of the economic mind of entrepreneurs, the Economic Attitudes Questionnaire (Deyneka, Zabelina, 2018) was used.

The data were processed using SPSS 24.0. statistical package. For the comparative analysis, the Mann-Whitney U criterion was used. Multivariate regression analysis was used to identify the impact of the components of psychological time on economic attitudes of the entrepreneurs.

\section{Results and discussion}

At the first stage, the features of economic attitudes of the entrepreneurs compared to hired employees were studied (Table 1). 
Table 1. Results of comparative analysis of economic attitudes of the entrepreneurs and hired employees.

\begin{tabular}{|c|c|c|c|c|c|c|}
\hline \multirow[t]{2}{*}{ Indicators } & \multicolumn{4}{|c|}{ Mean rank } & \multirow[t]{2}{*}{$\mathrm{U}$} & \multirow[t]{2}{*}{$\mathrm{p}$} \\
\hline & Entrepreneurs & IT professionals & $\begin{array}{l}\text { School } \\
\text { teachers }\end{array}$ & $\begin{array}{l}\text { Civil } \\
\text { servants }\end{array}$ & & \\
\hline $\begin{array}{l}\text { Financial } \\
\text { literacy }\end{array}$ & 220,64 & 216,15 & 180,13 & 209,62 & 7.627 & 0.054 \\
\hline $\begin{array}{l}\text { Willingness to } \\
\text { invest }\end{array}$ & 244,29 & 211,64 & 187,14 & 178,94 & 19.240 & 0.000 \\
\hline $\begin{array}{l}\text { Value of } \\
\text { independent } \\
\text { achievements }\end{array}$ & 228,47 & 183,36 & 208,97 & 209,42 & 10.006 & 0.019 \\
\hline $\begin{array}{l}\text { Financial } \\
\text { optimism }\end{array}$ & 262,11 & 226,24 & 161,21 & 168,86 & 51.877 & 0.000 \\
\hline $\begin{array}{l}\text { Customer } \\
\text { satisfaction }\end{array}$ & 232,47 & 213,89 & 174,83 & 204,14 & 13.177 & 0.004 \\
\hline $\begin{array}{l}\text { The priority of } \\
\text { the earnings } \\
\text { over vocation }\end{array}$ & 157,42 & 215,42 & 222,53 & 238,71 & 28.244 & 0.000 \\
\hline $\begin{array}{l}\text { The priority of } \\
\text { the earnings } \\
\text { over health }\end{array}$ & 178,80 & 216,55 & 216,09 & 218,94 & 8.609 & 0.035 \\
\hline
\end{tabular}

It was found that the entrepreneurs are more confident in their financial literacy $(\mathrm{H}=7.627$, $\mathrm{p}=0.054)$, they are more willing to invest in new projects $(\mathrm{H}=19.240, \mathrm{p}=0.000)$. Small business owners value independent achievements in the economic sphere more than most of employees do $(\mathrm{H}=10.006$, $\mathrm{p}=0.019$ ), they have more pronounced financial optimism - the belief that their income level will increase in the future $(\mathrm{H}=51.877, \mathrm{p}=0.000)$, and higher satisfaction with the possibilities of personal consumption $(\mathrm{H}=13.177 \mathrm{p}=0.004)$. These features are explained by the specifics of entrepreneurial activity (willingness to take risks, immersion in financial issues, willingness to rely on their own strength, etc.), and also indicate that entrepreneurs are the most active group of the population not only in the field of finance and investment, but also in the field of consumption.

Additionally, there was a lower degree of the agreement with the statement "I am ready to work for a large income even at the expense of my health" $(\mathrm{H}=8.609, \mathrm{p}=0.035)$ and "The key to well - being is to find a well-paid job, even if it is not your vocation" $(\mathrm{H}=28.244, \mathrm{p}=0.000)$. Most business owners believe that health and self-realization are more important values than money. Perhaps it is the desire for independence, the unwillingness to work for money in an unloved job (for hire) that pushes some people to open their own business.

Further, the assumption was tested whether the features of the psychological time of the entrepreneurs are the predictors of their economic mind and behavior. Regression analysis has shown that various components of psychological time determine the shaping of certain economic attitudes. A positive and active attitude to one's past, a positively meaningful experience contributes to the self-perception of an entrepreneur as a financially literate person $(\beta=-0.27, p=0.005)$. The ability to perceive and value time as an economic tool increases the desire and willingness to invest in promising, even risky, projects, calculate long-term profits $(\beta=0.24, \mathrm{p}=0.013)$.

For most entrepreneurs, people who have achieved everything in life themselves are an example to follow, a kind of ideal. Businesspersons treat such people with great respect and reverence, probably projecting this image on themselves. This belief is influenced by an emotionally positive attitude towards one's future $(\beta=-0.44, p=0.013)$, as well as a certain fatalism in the perception of present events $(\beta=0.21$, $\mathrm{p}=0.023$ ). It seems that entrepreneurs identify themselves with the image of a person who has "made" their own success; they believe that in the future they will also be able to achieve a lot, thanks to their own efforts. At the same time, this belief has for them a certain degree of fatality, predestination, given from above. They probably believe implicitly that their path in business is the only right one.

The largest number of indicators of psychological time is involved in the formation of financial optimism of the entrepreneurs. This phenomenon is based on a complex combination of the value of time as an economic resource $(\beta=0.37, \mathrm{p}=0.000)$, a positive emotional attitude to one's future as successful, joyful, manageable $(\beta=-0.25, \mathrm{p}=0.007)$, self-confidence in managing the events of the present $(\beta=-0.28$, $\mathrm{p}=0.002)$, the desire to enjoy the present moment $(\beta=0.27, \mathrm{p}=0.011)$ and the lack of fixation on positive events of the past $(\beta=-0.19, p=0.026)$. In fact, in this complex of predictors, one can see both rational phenomena (for example, the ability to convert time into monetary equivalent) and irrational ones 
(a certain degree of hedonism, optimistic expectations about the future, etc.). Probably, it is from the combination of a holistic perception of economic reality that optimism about their future financial situation develops.

\section{Conclusion}

Thus, the hypothesis about the relationship between psychological time and economic attitudes of entrepreneurs was confirmed. The absence of "obsession" with past failures, a positive attitude to the present and future, the ability to transfer time into money create a psychological foundation for the formation of entrepreneurs' positive attitudes in economic life, as well as for achieving satisfaction and well-being in it.

The results obtained can be used in the selection and psychological counseling of people participating in training programs for the entrepreneurs. It is necessary to pay attention (diagnose) not only personal qualities (independence, risk-taking, creativity, resilience, etc.), but also the attitude to time. The risk group for engaging in entrepreneurial activities can be people who are focused on their past failures and mistakes for a long time, as well as those who are inclined to believe that a person is not able to influence the circumstances.

The study involved only the entrepreneurs of small business from one Russian region, which is its main limitation. Further research should be conducted to verify the results obtained on the larger sample.

\section{Acknowledgments}

The research was funded by RFBR and Chelyabinsk Region, project number 20-413-740009.

\section{References}

Antonides, G., \& Van Der Sar, N.L. (1990). Individual expectations, risk perception and preferences in relation to investment decision making. Journal of Economic Psychology, 11 (2), 227-245

Chen, J.H., \& Nadkarni, S. (2017). It's about Time! CEOs' Temporal Dispositions, Temporal Leadership, and Corporate Entrepreneurship. Administrative Science Quarterly, 62 (1), 31-66

Conner, M., \& Sparks, P. (2002). Ambivalence and attitudes. European Review of Social Psychology, 12, $37-70$.

Deyneka, O.S. (2011). Economic mind: phenomenology, structure and potential development. In N.M. Lebedeva, \& A.N. Tatarko (Eds.). Culture and economic behavior: a collection of articles. Moscow: Maks Press, pp. 118-148. (In Rus.)

Deyneka, O.S., \& Zabelina, E.V. (2018). Multiple-factorial questionnaire for the express diagnostics of economic attitudes: the results of the development. Psikhologicheskie Issledovaniya, 11 (58), 9. Retrieved from http://psystudy.ru/index.php/eng/2018v11n58e/1567-deyneka58e.html (In Rus.)

Furnham, A. (1985). Why Do People Save? Attitudes to, and Habits of Saving Money in Britain. Journal of Applied Social Psychology, 15 (5), 354-373

Furnham, A. (1996). Attitudinal correlates and demographic predictors of monetary beliefs and behaviors. Journal of Organizational Behavior, 17 (4), 375-388.

Kalil, A., Schweingruber, H.A., \& Seefeldt, K.S. (2001). Correlates of employment among welfare recipients: Do psychological characteristics and attitudes matter? American Journal of Community Psychology, 29 (5), 701-723.

Lea, S.E.G., Webley, P., \&Walker, C.M. (1995). Psychological factors in consumer debt: Money management, economic socialization, and credit use. Journal of Economic Psychology, 16 (4), 681-701.

LeBlanc, A.F. (1969). Time Orientation and Time Estimation: A Function of Age. The Journal of Genetic Psychology, 115, 187-194.

Lewis, A., \& Furnham, A. (1986). Reducing unemployment: Lay beliefs about how to reduce current unemployment. Journal of Economic Psychology, 7 (1), 75-85.

Mewse, A.J., Lea, S.E.G., \& Wrapson, W. (2010). First steps out of debt. Attitudes and social identity as predictors of contact by debtors with creditors. Journal of Economic Psychology, 31 (6), 1021-1034 
Mitina, O.V., \& Sircova, A. (2008). Questionnaire on Time Perspective of F.Zimbardo (ZTPI) results of the psychometric analysis of the Russian version. Moscow University Psychology Bulletin, 4, 67-89 (In Rus).

Nestik T.A. (2015). Social'no-psihologicheskaya determinaciya gruppovogo otnosheniya $k$ vremeni [Social and psychological determination of group attitude to time] Doctoral thesis. Moscow (In Rus.)

Nuttin, J.M. (2004). Motivaciya, dejstvie i vremennaya perspektiva budushchego [Motivation, action and a future time perspective]. Moscow: Smysl. (in Rus.)

Przepiorka, A. (2016) What makes successful entrepreneurs different in temporal and goal-commitment dimensions? Time \& Society, 25 (1), 40-60

Przepiorka, A. (2017) Psychological Determinants of Entrepreneurial Success and Life-Satisfaction. Current Psychology, 36 (2), 304-315

Retsikas, K. (2017) The gift of future time: Islamic welfare and entrepreneurship in 21st century Indonesia. South East Asia Research, 25 (3), 284-300

Rokeach, M. (1986). The Nature of Attitudes. In D. L. Sills (Ed.) International Encyclopedia of the Social Sciences, Crowell.

Smith, M.B. (1986). Attitude Change. In D. L. Sills (Ed.) International Encyclopedia of the Social Sciences, Crowell.

Von Stumm, S., Fenton O'Creevy, M., \& Furnham, A. (2013). Financial capability, money attitudes and socioeconomic status: Risks for experiencing adverse financial events. Personality and Individual Differences, 54 (3), 344-349.

Zabelina, E., Deyneka, O., \& Tsiring, D. (2019). Entrepreneurial attitudes in the structure of students' economic minds. International Journal of Entrepreneurial Behavior \& Research, 25(8), 1621-1633.

Zhuravlev, A.L. (2005). Economic psychology: a place and role in modern science. Russian Psychological Journal, 2 (1), 45-56 (In Rus.).

Zhuravlev, A.L., \& Kupreichenko, A.B. (2007). Economic self-determination of youth: structure and determination. Bulletin of Practical Psychology of Education, 1, $50-55$ (In Rus.).

Zimbardo, P.G., \& Boyd, J.N. (1999) Putting time in perspective: A valid, reliable individual-differences metric. Journal of Personality and Social Psychology, 77 (6), 1271-1288. 